\title{
Late Holocene Vegetation History and Early Evidence of Araucaria angustifolia in Caçapava do Sul in the Lowland Region of Rio Grande do Sul State, Southern Brazil
}

\author{
Hermann Behling $^{1 *}$; Nuno Verissimo ${ }^{2}$; Soraia Bauermann ${ }^{3}$; Sergio Bordignon ${ }^{3}$; Andreia \\ Evaldt $^{3}$ \\ ${ }^{1}$ University of Göttingen, Dept. Palynology and Climate Dynamics, Untere Karspüle, Germany. ${ }^{2}$ Nationale \\ Plantentiun van België, Bruselles, Belgium. ${ }^{3}$ Universiade Luterana do Brasil, Canoas, Rio Grande do Sul, Brasil.
}

\begin{abstract}
Little is known about the southernmost occurrence of small areas with Araucaria angustifolia populations in Caçapava do Sul in low elevated areas of Rio Grande do Sul State, about $130 \mathrm{~km}$ to the south of to the highlands of southern Brazil where the main distribution of Araucaria is found. This occurrence is about $130 \mathrm{~km}$ further south to the main area of Araucaria angustifolia which is on the highlands in southern Brazil. The question is whether this occurrence is natural, due to indigenous peoples, or due to plantation by post-Columbian settlers. To trace the origin of this little known southernmost existence of Araucaria angustifolia trees is of particular interest for conservation issues. To address this question we did a vegetation survey and studied a $150 \mathrm{~cm}$-long radiocarbon dated sediment core from the Fazenda da Mônica by pollen analysis. The vegetation survey of the study area indicates that also other typical taxa of the Araucaria forest as well as the Atlantic lowland rainforest are found in the present-day semi-deciduous forest, such as Podocarpus, Ilex, Myrsine and Prunus for the former, and Alchornea, Moraceae, Arecaceae, and Myrtaceae for the later. The pollen record, due to bad pollen preservation, starts only after $44 \mathrm{~cm}$ core depth, which is about 515 cal yr BP old (AD 1490), indicating that Araucaria angustifolia as well as other Araucaria forest and Atlantic rainforest taxa occurred in this area since the beginning of the pollen record. The occurrence of these taxa can be seen as natural and not introduced during the post-Columbian colonisation. First settlers at the beginning of the 19th century reduced existing population of Araucaria markedly and in particular since about AD 1950. The population of Araucaria angustilfolia before the post-Columbian settlement was much larger than today.
\end{abstract}

Key words: Late Holocene, Araucaria angustifolia, pollen analysis, southern Brazil

\footnotetext{
*Author for correspondence: hbehlin@gwdg.de
} 


\section{INTRODUCTION}

In the lowland of Rio Grande do Sul State, small isolated Araucaria angustifolia (Bertol.) Kuntze populations can be observed in the region of Caçapava do Sul, such as in the Fazenda Santa Mônica. This location is about $130 \mathrm{~km}$ to the south of the southernmost occurrence of Araucaria forest in the southern Brazilian highlands (Fig. 1).

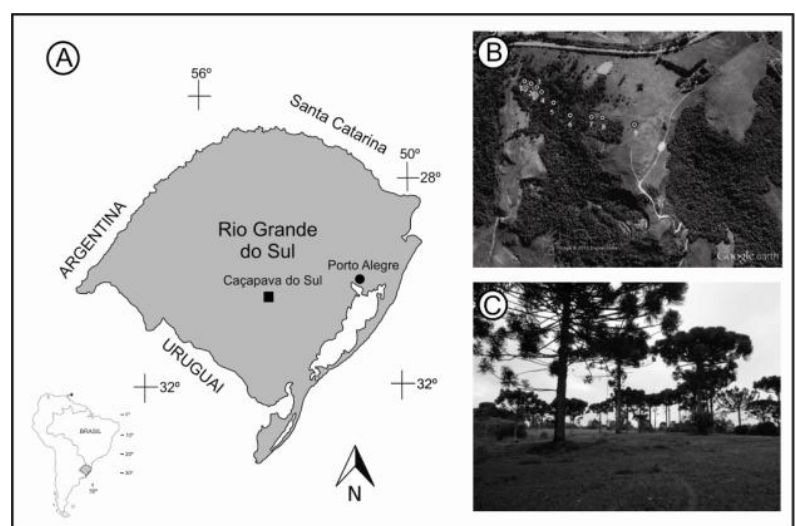

Figure 1- Map showing the study site in the Caçapava do Sul region in Rio Grande do Sul State (A) and the Fazenda Santa Monica (B) with trees of Araucaria angustifolia (C).

According to the survey on the distribution of Araucaria angustifolia in Brazil by Hueck (1953, 1966), there is no evidence of the natural distribution of this tree in the lowlands of Rio Grande do Sul. It is therefore possible that this occurrence is due to post-Columbian settlers, which would have planted these trees on their lowland farms for wood as well as for the nutrient supply provided by the seeds (Cordenunsi et al. 2004; Bello-Perez et al. 2006). First settlers from Portugal arrived to the region during the early $19^{\text {th }}$ century (Corrêa 2013). Nevertheless, a natural occurrence of Araucaria angustifolia, perhaps as a relict of former larger glacial population (forest refugia), could be possible, and somewhat wetter small locations in the lowland Rio Grande do Sul would have maintained Araucaria angustifolia throughout the Holocene. Another scenario could be that indigenous people transported seeds to the lowlands, as it is known that the seeds of Araucaria were an important nutrient source for indigenous people (Iriarte and Behling 2007). Before colonization, Caçapava do Sul was habituated by indigenous; there is evidence that humans already lived in the region about $11,000-$ 9000 years ago (Farias et al. 2005). However, if the occurrence of small Araucaria angustifolia populations is natural, these areas should be conserved. Due to the above mentioned aspects, it is of particular interest to know more about the history of Araucaria angustifolia in the lowlands of Rio Grande do Sul State.

The history of the Araucaria forest on the southern Brazilian highlands has been focused on by several studies, but almost nothing is known about the isolated occurrence of Araucaria angustifolia in the lowlands of Rio Grande do Sul. Pollen analytical studies from the modern Araucaria forest and Campos regions of the southern Brazilian highlands provide insights on the vegetation history. Results from Paraná (Serra Campos Gerais: Behling 1997), Santa Catarina (Serra do Rio Rastro, Morro da Igreja, Serra da Boa Vista: Behling 1993; 1995) and Rio Grande do Sul (Aparados da Serra: Roth and Lorscheitter 1993; São Francisco de Paula: Behling et al. 2001; Cambará do Sul: Behling et al. 2004; 2007; Leonhardt and Lorscheiter 2010; Jeschke et al. 2012) showed that extensive areas of Campos vegetation existed on the highlands throughout the late-Glacial and early to mid-Holocene times. The dominance of Campos vegetation was attributed to drier climates, cold and dry during the late-Glacial, and warm and dry during the early Holocene (Behling 1997). An annual dry season lasting about three months was probably characteristic of the early and mid- Holocene period (Behling 1997). About 4000 years ago, expansion of the Araucaria forests started by migration through the gallery forests along the rivers, indicating a shift to a somewhat wetter climate. A marked expansion of Araucaria forests on the highlands, replacing Campos vegetation began in Paraná State (Serra Campos Gerais) about 1500 years ago and in Santa Catarina and Rio Grande do Sul State in general about 1000 years ago. This is a period well within the late Holocene's very humid climate without a marked annual dry period. Araucaria forest apparently continues to expand today on the highlands under natural conditions (e.g. Klein 1960, 1975). Records from the southern Brazilian lowlands (São Francisco de Assis: Behling et al. 2005) show that the lowland of western Rio Grande do Sul State has been covered with natural Campos vegetation continuously from 22,000 yr BP. Modern gallery forests did not exist during glacial times and developed in the form of small strips along rivers only after $5170 \mathrm{yr}$ BP; gallery forest expansion occurred after $1550 \mathrm{yr} \mathrm{BP}$, with a 
Late Holocene Vegetation History and Early Evidence of Araucaria angustifolia in Caçapava do Sul in the Lowland Region of Rio Grande do Sul State, Southern Brazil

maximum at $1090 \mathrm{yr} \mathrm{BP}$, reflecting a change to wetter climatic conditions. The São Francisco de Assis record indicates no evidence of Araucaria angustifolia in that area. Genetic studies on Araucaria angustifolia on southeastern and southern Brazilian highland indicate evidences of genetic bottlenecks (Stefenon et al. 2008).

So far nothing is known about the vegetation history in the region of the Caçapava do Sul region despite the importance of possible conservation and management of small isolated Araucaria populations. Important research questions in this study are: 1) Is the modern vegetation composition with Araucaria angustifolia at Santa Mônica reflecting a vegetation type which corresponds to a typical vegetation of Araucaria forest from the highland? 2) What is the origin of Araucaria angustifolia in the lowland of Rio Grande to Sul? 3) Since when Araucaria angustifolia occurred in the area under study? 4) Is the presence of Araucaria angustifolia in the lowland of Rio Grande to Sul natural or a result of introduction by indigenous people or post-Columbian settlers? To address these research questions, we studied modern vegetation and a radiocarbon dated sediment core from the Fazenda Santa Mônica.

\section{STUDY SITE}

The study site, Fazenda Santa Mônica, is found near the village Caçapava do Sul and close to the road BR-392, in the municipality of Caçapava do Sul, in the southeastern lowland part of Rio Grande do Sul (Fig. 1), The site is about $225 \mathrm{~km}$ to the west of Porto Alegre. The studied site is located at $30^{\circ} 20^{\prime} \mathrm{S}, 53^{\circ} 18^{\prime} \mathrm{W}$, at $430 \mathrm{~m}$ a.s.l. at the so-called Serra do Sudeste, a low-lying mountain range found in the southeastern part of the State. The studied site consists on a swamp formed in a small basin about $4 \mathrm{~m}$ long and $3 \mathrm{~m}$ wide.

The atmospheric circulation of southern Brazil is dominated by the South Atlantic Anticyclone, a semi-permanent high-pressure system which transports moist tropical air masses over the continent in an easterly and north-easterly direction during the whole year. Disturbances to this pattern are related to perturbations of polar cold fronts, which, upon meeting tropical air masses, produce heavy rainfall in southern Brazil (Nimer 1989; Hastenrath 1991).

The Serra do Sudeste region is characterised by a mesothermic, humid climate without marked dry periods (Nimer 1989). The nearest climate station is Encruzilhada do Sul (http://www.bdclima.cnpm.embrapa.br/), about 90 $\mathrm{km}$ to the east of the study site at an elevation of $427 \mathrm{~m}$. It recorded a mean annual precipitation of $1541 \mathrm{~mm}$ (between 1961 - 1990), and a mean annual temperature of $17.1^{\circ} \mathrm{C}$. The lowest measured average monthly temperature is $12.2^{\circ} \mathrm{C}$ in June and July.

The vegetation in the municipality of Caçapava do Sul, as part of the Serra do Sudeste, is mainly characterised by a mosaic of semi-deciduous forest and Campos (grassland). The Campos are rich in species of the families Poaceae, Asteraceae and Cyperaceae. Forest is normally found only along the rivers (Trindade and Borba 2011). At the present-day, the vegetation of the region is mostly determined either by frequent pasturing activities or the use of fire, which are detrimental to woody species, so that only small remnants of forest remain. Some areas are reforested with pine trees. The local vegetation surrounding the forest coring site is Campos used as pasture land.

\section{MATERIAL AND METHODS}

\section{Vegetation survey}

Plant species which occur in the study area (both in the forest as well in the Campos vegetation) have been identified during field visits in 2011 and 2012. The identified species have been grouped according to their ecological preferences into two vegetation types: semi-deciduous forest and the Campos.

\section{Sampling and pollen analytical studies}

The Santa Mônica core was collected in 2005 using a Russian corer. A $150 \mathrm{~cm}$-long sediment core was collected in $50 \mathrm{~cm}$ sections from the deepest part of the small swamp. The sections were stored in situ in splitted PVC tubes, wrapped in plastic and aluminium film and stored under refrigeration $\left(+4^{\circ} \mathrm{C}\right)$ after return from the field and before sampling.

One bulk sample of $1 \mathrm{~cm}$ of thickness was taken for radiocarbon dating at $47 \mathrm{~cm}$ core depth and sent to the radiocarbon laboratory at the University of Nürnberg-Erlangen, Germany. The radiocarbon age was calibrated using Calib 7.0 (Reimer et al. 2013).

In total 39 samples of $1 \mathrm{~cm}^{3}$ were taken for pollen analysis along the entire core: every $2 \mathrm{~cm}$ between depths 0 and $50 \mathrm{~cm}$, every $4 \mathrm{~cm}$ between depths 50 and $100 \mathrm{~cm}$, and two samples at $133 \mathrm{~cm}$ and 143 
$\mathrm{cm}$ (the sandy nature of the core made a more regular sampling impossible). In order to calculate pollen concentration a tablet of exotic Lycopodium spores was added to each sample.

Pollen grains and spores were counted on pollen slides under 400x magnification. Pollen content of the samples was in general very low and samples below $44 \mathrm{~cm}$ core depth were almost barren of pollen. We aimed to count at least a minimum of 100 pollen grains per sample, but a few samples with at least 50 pollen grains where still considered.

Percentages of all taxa were calculated based on the pollen sum, which includes all pollen types. Taxa have been assigned to the groups "Semideciduous forest", "Campos", "Unknowns" and "Pteridophyta".

The zonation of the pollen diagram (Fig. 2) was established by means of a CONISS analysis for stratigraphically constrained samples (Grimm 1987). Spores were not considered for this analysis.

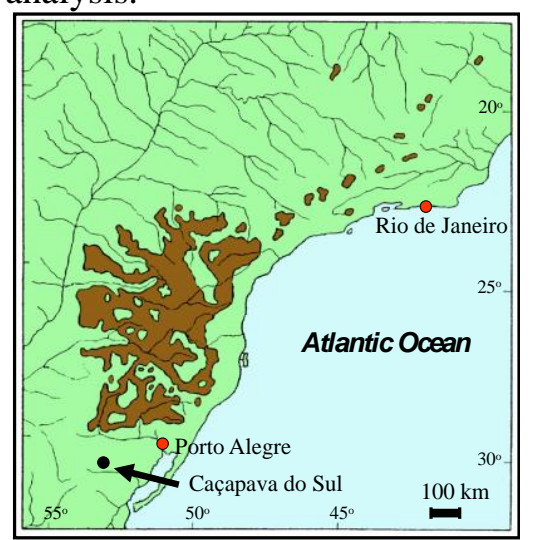

Figure 2- Map showing the distribution of Araucaria forests in Brazil (adapted after Hueck 1953) and the study site in the Caçapava do Sul region where the Fazenda Santa Mônica is located.

\section{RESULTS}

\section{Vegetation survey}

About 100 plant species were identified at the study site Fazenda Santa Mônica and are shown in Table 1 . The results show that not only Araucaria angustifolia itself but also several other taxa typical of the Araucaria forest of the highlands in southern Brazil, such as Podocarups, Ilex, Myrsine and Prunus, occur today in the study area. Podocarpus lambertii Klotzsch ex Endl. has been observed in the study region, but not in the Fazenda itself. A number of species belonging to the Atlantic rainforest, such as Alchornea, Moraceae, Arecaeceae, Myrtaceae, were recorded at the study site as well.

Table 1- List of identified plant species at the study site Fazenda Santa Mônica.
Semi-deciduous forest
Piper xylosteoides Steud.
Acalypha $\mathrm{L}$.
Adianthopsis chlorophylla (Sw.) Fée
Prunus myrtifolia (L.) Urb.
Adiantum raddianum Presl.
Rubus sp. L.
Alophyllus edulis (A. St. -Hil.) Niederl.
Aloysia gratissima (Gillies \& Hook.) L.D. Benson
Sebastiania brasiliensis Spreng.
Anemia phylitidis (L.) Sw.
Smilax sp. L.
Solanum aculeatissimum Jacq.
Baccharis anomala DC.
Banara parviflora Benth.
Symplocos uniflora Benth.
Blechnum australe (L.) subsp. auriculatum (Cav.) Tynanthus elegans Miers.
la Sota
Blepharocalyx salicifolia $\mathrm{O}$. Berg T
Zanthoxylum fagara Sarg
Bromelia antiacantha Bertol.
Casearia sylvestris $\mathrm{Sw}$.
Campos
Cedrela fissilis Vell.
Andropogon lateralis Nees

Psychotria leiocarpa Cham. \& Schltdl.

Syagrus romanzoffiana (Cham.) Glassman 
Late Holocene Vegetation History and Early Evidence of Araucaria angustifolia in Caçapava do Sul in the Lowland Region of Rio Grande do Sul State, Southern Brazil

Celtis sp. L.

Cestrum sp. L.

Chiococca alba (L.) A.S. Hischc.

Chrysophyllum marginatum (Hook. et Arn.) Radlk.

Cupania vernalis Cambess.

Cyathea atrovirens (Langsd. \& Fisch.) Domin

Daphnopsis racemosa Griseb.

Dodonaea viscosa Jacq.

Doryopteris pedata var. multipartita

R.m.Tryon T

Eugenia hyemalis Cambess.

Faramea montevidensis DC.

Forsteronia glabrescens Müll. Arg.

Gochnatia polymorpha (Less.) Cabrera

Guettarda uruguensis Cham. \& Schltdl.

Heimia myrtifolia Cham. \& Schltdl.

Helietta apiculata Benth.

Huperzia sp. Bernh.

Hyptis mutabilis Briq.

Ilex sp.

Lantana montevidensis (Spreng.) Briq.

Lithraea molleoides Engl.

Luehea divaricata Mart.

Macroptilium prostratum (Benth) Urb.

Mandevilla erecta Woodson

Matayba elaeagnoides Radlk.

Maytenus ilicifolia Mart. Ex Reiss.

Miconia Ruiz \& Pav.

Mikania glomerata Spreng.

Mutisia coccinea A. St. Hill.

Myrceugenia myrtoides O. Berg

Myrsine L.

Ocotea pulchella Mart.
Andropogon selloanus Hack.

Aristida L.

Axonopus affinis Chase

Baccharis articulata Pers.

Baccharis dracunculifolia DC.

Borreria brachystemonoides Cham. \& Schltdl.

Campomanesia aurea $\mathrm{O}$. Berg.

Conyza Less.

(Fée) Crotalaria hilariana Benth.

Cuphea glutinosa Cham. \& Schltdl.

Desmodium Desv.

Eragrostis neesii Trin.

Eryngium sanguisorba Cham. \& Schltdl.

Glechon ciliata Benth.

Hybanthus bicolor (A. St. Hil.) Baill.

Hypochaeris sp. L.,

Lupinus L.

Pfaffia tuberosa (Moq. ex DC.) Hicken

Paspalum nicorae Parodi

Paspalum notatum Flügge

Paspalum plicatulum Michx.

Schizachyrium microstachyum (Desv. ex Ham.)

Roseng.

Scoparia plebeia Cham. \& Schltd.

Solidago chilensis Meyen

Sporobolus R.Br.

Stachytarpheta cayanensis Vahl

Stylosanthes montevidensis Vogel

Tibouchina Aubl.

Verbena officinalis $\mathrm{L}$.

Vernonia Schreb.

Walenbergia linarioides (Lam.) DC.

Zornia reticulata $\mathrm{Sm}$.
Stratigraphy and Chronology of the sediment core Santa Mônica

The $150 \mathrm{~cm}$-long sediment core varies in terms of both colour and composition. Between 150 and 20 $\mathrm{cm}$ core depth, a grey clayish sandy sediment with little organic content is found. The amount of fine sand decreases upwards, but is high between 150$104 \mathrm{~cm}$ and 90-72 $\mathrm{cm}$. Between 20 and $11 \mathrm{~cm}$, dark brown organic sediment with fine sand occurs; between 11 and $5 \mathrm{~cm}$, grey clayish organic sediment with almost no roots; and between 5 and $0 \mathrm{~cm}$ light brown organic sediment rich in roots. The radiocarbon age of the dated sample at $47 \mathrm{~cm}$ core depth is $427 \pm 43 \mathrm{yr} \mathrm{BP}($ Erl-12103). The calibrated age using the freeware application Calib 7.0 (http://calib.qub.ac.uk/calib/calib.html) is cal AD 1428-1490 to cal AD 1603-1610 (1 sigma) with the highest probability at cal AD 1455, indicating that the dated sample is about 550 years old. The core depth at $44 \mathrm{~cm}$, where the pollen record start would be than at about cal AD 1490 and about 515 years old. Assuming that the top sample represents the present-day (AD 2005) and sedimentation rate of the $44 \mathrm{~cm}$ were relatively constant, the ages of each pollen zone have been calculated (see below).

\section{Description of the pollen diagram Santa Mônica}

Due to the low pollen content of the studied sediment core, only 19 samples (starting from core depth of $44 \mathrm{~cm}$ ) out of the original 39 prepared samples had a reasonable minimum of pollen to be used. In total 55 pollen types, including 15 
unknown pollen types, and 9 spore types were found (Table 2). The CONISS analysis allows the distinction of three pollen zones (Fig. 3). Due to the one single radiocarbon date, calculated ages should be seen only as a rough estimation.

Table 2- Identified pollen and spore types found in the Santa Mônica core, listed according to the different vegetation types they were assigned to for the pollen analysis (pollen types with an asterisk were only present in one sample).

\begin{tabular}{ll}
\hline Semi-deciduous forest & Baccharis type \\
Alchornea & Croton type \\
Araucaria angustifolia & Cyperaceae \\
Arecaceae & Ericaceae \\
Banara/Xylosma type & Fabaceae \\
Buddleja type & Iridaceae type \\
Caesearia decandra & Oxalis \\
Cecropia & Plantago australis type \\
Didymopanax* & Plantago turficola type \\
Dodonea & Poaceae \\
Gallesia & Senecio type \\
Ilex & Vernonia type \\
Matayba & \\
Melastomataceae & Exotic \\
Moraceae/Urticaceae & Alnus \\
Myrsine & \\
Myrtaceae & Unknown \\
Podocarpus & 15 different unknown types \\
Prockiscrucis type & \\
Prunus type & Pteridophyta \\
Rubiaceae & Anemia phyllides type \\
Styrax $*$ & Cyathea schanschin type \\
Symplocos lanceolata type & Huperzia \\
Symplocos tenuifolia type & Lycopodium clavatum type \\
Campos & Monolete spores (psilate type) \\
Amaranthaceae/Chenopodiaceae type & Monolete spores (verrucate type) \\
Ambrosia type & Pteris \\
Apiaceae type & Selaginella type \\
Asteraceae type & Trilete spores (psilate type) \\
\hline & \\
\hline
\end{tabular}


Late Holocene Vegetation History and Early Evidence of Araucaria angustifolia in Caçapava do Sul in the Lowland Region of Rio Grande do Sul State, Southern Brazil

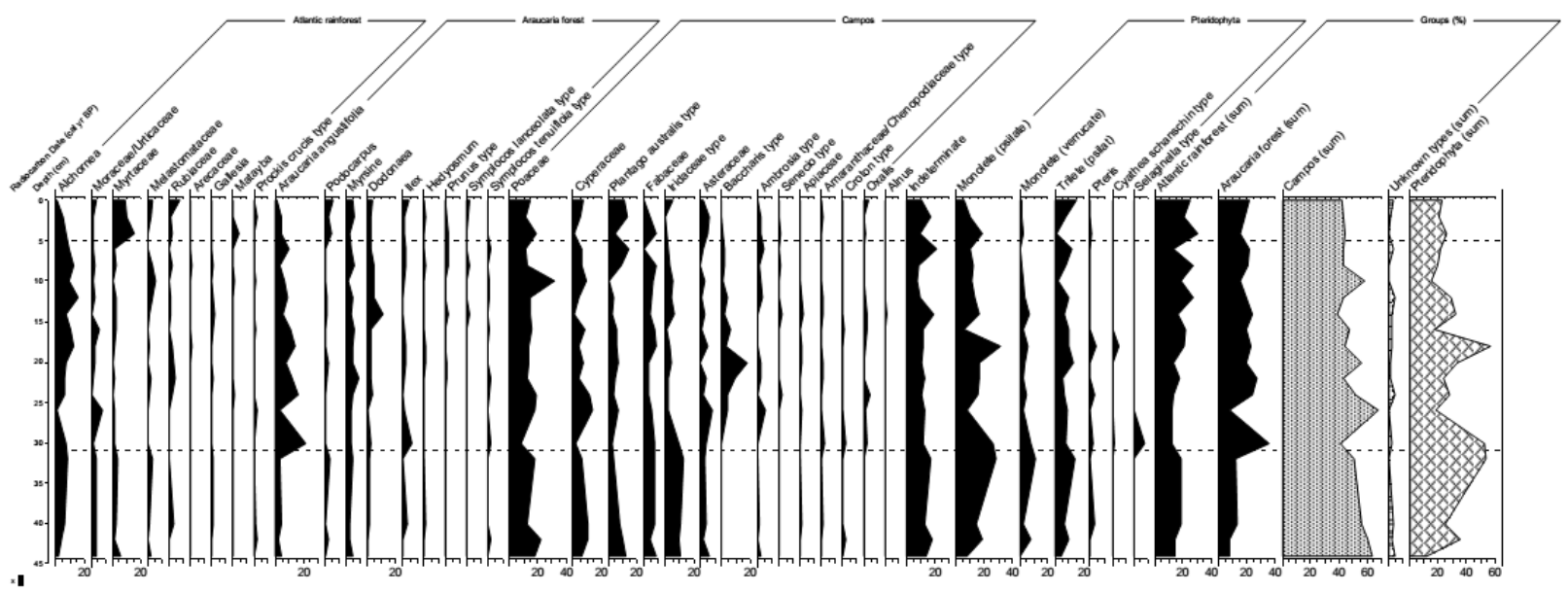

Figure 3- Pollen percentage diagram from Santa Mônica showing selected most frequent pollen and spore taxa, total pollen sum and the sum of the grouped taxa Atlantic rainforest, Araucaria forest, Campos and Pteridophyta.

Zone SM-I (44 - $31 \mathrm{~cm}$; cal AD 1490 - 1650; 4 samples): Within the group of Semi-deciduous forest pollen (16\%), Alchornea (5\%), Moraceae/Urticaceae (5\%) and Myrtaceae (3\%) Araucaria angustifolia (3\%) and Myrsine (3\%) are the most common taxa. The pollen assemblages is however clearly dominated by Campos pollen (around 56\%), with Poaceae (17\%), the Iridaceae type $(11 \%)$, the Plantago australis type $(8 \%)$, and Cyperaceae (8\%) being the most common taxa. Pteridophyte spore taxa are well represented (31\%) mainly by monolete and trilete psilate types.

Zone SM-II (31 - 5 cm; cal AD 1650 - 1950; 12 samples): Pollen sums of the Semi-deciduous forest group increase mainly due to the higher abundance of Araucaria angustifolia (up to 16\%), Alchornea (9\%), whereas other taxa become either less or only slightly more common. Araucaria angustifolia pollen has its highest values at the beginning of the zone (16\%) and decreases afterwards, particularly during the upper part of the zone (10 to 5\%). Dodonaea pollen increases during the second half of the zone. The proportion of the Campos pollen group is slightly less frequent $(47 \%)$. Pollen of Poaceae $(15 \%)$, the Plantago australis type (5\%), and Cyperaceae
$(6 \%)$ are more or less as abundant as in the zone before. Pollen of the Iridaceae type decreases (4\%) and the Baccharis type becomes more abundant (average of 5\%) as well as the Ambrosia type (3\%). Pteridophyte spores become only slightly less frequent (29\%). A few spores of the Cyathea schanschin type occur in this zone.

Zone SM-III (5 - 0 cm; cal AD 1950 - 2005; 3 samples): In the uppermost zone, Semi-deciduous forest pollen increases slightly, in particular Myrtaceae (11\%), while Alchornea decreases (2\%). Pollen of Araucaria angustifolia becomes rare (3\%), while Podocarpus pollen (4\%) increases markedly. Within the Campos group $(43 \%)$, the pollen assemblage varies a little with Poaceae (15\%), the Plantago australis type (10\%), and Cyperaceae (4\%) being the most common taxa. The Iridaceae type is even less frequent in this zone $(2 \%)$ and the Baccharis type is almost absent. Spores of pteridophytes are slightly less frequent (23\%), with the decreasing abundance of monolete psilate spores (11\%).

\section{INTERPRETATION AND DISCUSSION}

The study of the modern vegetation indicates that different species of both Araucaria forest as well 
as of the Atlantic rainforest are found today in the study area of Fazenda Santa Mônica. This indicates a mixed semi-deciduous forest community on which some may have migrated to the study area. Studies on the migration of plants into southern Brazil have been carried out by several authors such as Rambo (1961), Reitz and Klein (1964) and Klein (1975;1980). They showed that there were several plant migration routes to southern Brazil during the Holocene. Several species migrated into the western lowlands in Rio Grande do Sul from the eastern Atlantic coastal lowland and from the western Rio Paraná valley during the past. Pollen analytical studies from the São Francisco de Assis core in western Rio Grande do Sul mention pollen of Myrsine at about $5000 \mathrm{cal} \mathrm{yr} \mathrm{BP}$ and a later occurrence of Moraceae indicates migration of species from both forest areas. Furthermore, the evidence of Cecropia pollen at $2880 \mathrm{cal} \mathrm{yr}$ BP indicates migration from the Atlantic coastal lowland, where the genus is restricted at present, to the western lowlands of Rio Grande do Sul. The migration route was likely along the lowlands south of the South Brazilian highlands and north of the crystalline shield, where at present Cecropia and other typical Atlantic rainforest taxa, such as Euterpe edulis Mart., reach sites ca. $250 \mathrm{~km}$ eastward from the study area (Behling et al. 2005).

The interpretation of the pollen record concerning the vegetation history of the Caçapava do Sul region has to be done carefully because of the relatively low pollen content of the core. Nevertheless, despite the low pollen content, it gives us interesting insights into the vegetation history of the past 500 years.

The pollen data show a relatively good representation of different taxa belonging to both forest and Campos vegetation, thus reflecting a mosaic of forest and Campos in the study area during the last 500 years. The proportion of forest and grassland was relatively stable, while the composition changed. Pollen of forest taxa suggest a mixture of populations, which belong to the Atlantic rainforest and the Araucaria forest. Pollen data reflect that Araucaria forest taxa such as Araucaria, Podocarpus, Myrsine, Ilex were well established at the study area.

Most of these taxa occurred already since the beginning of the record (zone SM-I), including Araucaria angustilfolia itself. The amount of Araucaria pollen, 3\% of the total pollen sum, further clearly indicates that populations of
Arancaria trees occurred in the study area. Long distance transport of single pollen grains from the highland, which is about $130 \mathrm{~km}$ distance to the north to the study site, is possible, but the amount of pollen present would then be much lower, as shown by the pollen rain study in the Atlantic lowland of northeastern Santa Catarina State (Behling and Negrelle 2006).

A stronger change is evident by the marked increase of Araucaria angustilfolia pollen (up to $16 \%$ in zone SM-II) at around cal AD 1650. It is possible that this increase reflects a better preservation of pollen grains, but this is not indicated by a change in the deposition. More likely is also that a change to slightly wetter conditions favoured the expansion. The evidence of a few spores of the tree fern Cyathea schanschin Mart. support this suggestion, as tree ferns require permanent humid conditions (Troll 1970). The stronger decrease of Araucaria angustilfolia is found after $15 \mathrm{~cm}$ core depth, what would be around cal AD 1830. This fits well to the colonisation of the Caçapava do Sul region which started by Portuguese settlers around the early $19^{\text {th }}$ century between AD 1821-1850 (Corrêa 2013). It is well known that trunks of Araucaria trees are excellent for wood constructions and first settlers took Araucaria trees from the forest. The strongest decrease after $5 \mathrm{~cm}$ core depth (zone SM-III) after around cal AD 1950 may reflect the logging of Araucaria trees by humans due to a stronger exploitation since that time.

Podocarpus and in particular Myrtaceae (zone SM-III) became quite common with the reduction of Araucaria in the forest. A similar marked increase of Myrtaceae has also been found on the highlands of the Cambará do Sul region (Behling et al. 2004), when they form the bulk of the secondary forest after Araucaria trees have been logged.

\section{CONCLUSIONS}

The modern forest composition with Araucaria angustifolia at Fazenda Santa Mônica indicates that also other typical Araucaria forest taxa occur in the study area, such as Podocarups, Ilex, Myrsine and Prunus. Taxa typical of the Atlantic rainforest are however equally found, such as Alchornea, Moraceae, Arecaeceae, Myrtaceae.

Despite the limitations in analysing palynologically the Santa Mônica core, this study 
Late Holocene Vegetation History and Early Evidence of Araucaria angustifolia in Caçapava do Sul in the Lowland Region of Rio Grande do Sul State, Southern Brazil

provides important insights on the vegetation history and occurrence of Araucaria angustilfolia in the Caçapava do Sul region of Rio Grande do Sul. The modern forest composition in the study area, and in particular the pollen record of Santa Mônica for the last 500 years, indicates that the occurrence of Araucaria angustilfolia is natural. The post-Columbian settlers did not introduce Araucaria from the southern Brazilian highland where the main distribution area is found. On the contrary, the first settlers - at the beginning of the $19^{\text {th }}$ century - started to reduce the already existing population of Araucaria markedly, a reduction particularly strengthened since about AD 1950. Therefore, as the pollen record indicates, the population of Araucaria angustilfolia before the post-Columbian settlement was much larger.

At the light of the evidence of natural Araucaria angustifolia populations in the Serra do Sudeste in lowland Rio Grande do Sul at least since the last 500 years and also its increasing destruction during the last decades, we would strongly recommend to protect the few areas still remaining. This area is probably also an important source for the genetic variability of Araucaria angustifolia as well as other species.

However due to the presence of other taxa typically found in the Araucaria forest, it seems to be unlikely that indigenes people introduced Araucaria to the area. However, it cannot be completely excluded that indigenes people did that before AD 1500. This aspect can be still addressed by future studies on other environmental archives which still needs to be found. Also the origin of many other species in that region needs still to be explored in detail.

\section{ACKNOWLEDGEMENTS}

We thank the owner of the Fazenda Santa Mônica Alfredo Brum for the kind permission to conduct the vegetation survey and the studied sediment core.

\section{REFERENCES}

Behling H, Bauermann SG, Neves PC. Holocene environmental changes from the São Francisco de Paula region, southern Brazil. J of South Am Earth Scien. 2001;14: 631-639.

Behling H, Pillar V, Bauermann SG. Late Quaternary grassland (Campos), gallery forest, fire and climate dynamics, studied by pollen, charcoal and multivariate analysis of the São Francisco de Assis core in western Rio Grande do Sul (southern Brazil). Review Palaeob Palynol. 2005;133: 235248.

Behling H, Pillar V, Orlóci L, Bauermann SG. Late Quaternary Araucaria forest, grassland (Campos), fire and climate dynamics, studied by high resolution pollen, charcoal and multivariate analysis of the Cambará do Sul core in southern Brazil. Palaeogeog, Palaeoclimatol Palaeoecol. 2004; 203: 277-297.

Behling H, Pillar V. Late Quaternary vegetation, biodiversity and fire dynamics on the southern Brazilian highland and their implication for conservation and management of modern Araucaria forest and grassland ecosystems. Philos Transact of the Royal Soc of London Series B Biolog Sci. 2007;362: 243-251.

Behling H. 1993. Untersuchungen zur spätpleistozänen und holozänen Vegetations- und Klimageschichte der tropischen Küstenwälder und der Araukarienwälder in Santa Catarina (Südbrasilien). Dissertationes Botanicae 206; Cramer, Berlin, Stuttgart: J. Cramer.

Behling H. Investigations into the Late Pleistocene and Holocene history of vegetation and climate in Santa Catarina (S Brazil). Veget Hist and Archaeob. 1995; 4: 127-152.

Behling H. Late Quaternary vegetation, climate and fire history in the Araucaria forest and campos region from Serra Campos Gerais (Paraná), S Brazil. Review of Palaeob and Palynol. 1997; 97: 109-121.

Behling H, Negrelle RRB. Vegetation and pollen rain relationship from the tropical Atlantic rain forest in southern Brazil. Braz Arch of Biol and Techn. 2006; 49: 631-642.

Bello-Perez LA, Garcia-Suarez FJ, Mendez-Montealvo G, Oliveira do Nascimento JR, Lajolo MF, Cordenunsi BR. Isolation and characterisation of starch from seeds of Araucaria brasiliensis: a novel starch for application in food industry. Starch. 2006; 58: 283-291.

Boldrini II, Ferreira PMA, Andrade BO, Schneider AA, Setubal RB, Trevisan R, et al. 2010. BIOMA PAMPA diversidade florística e fisionomia. Porto Alegre: LEV Camp / UFRGS.

Cordenunsi BR, Wenzel de Menezes E, Genovese MI, Colli C, Goncalvez de Souza A, Lajolo FM. Chemical composition and glycemic index of Brazilian Pine (Araucaria angustifolia) seeds. J Agricul Food Chim. 2004;52: 3412-3416.

Corrêa AdoN. Sociedade Agrária: hierarquia entre os criadores de gado vacum de Caçapava do Sul (18211850). Revista Eletrônica História em Reflexão. 2013; $7:$ 1-20.

Faegri K, Iversen J. 1989. Textbook of Pollen Analysis, 4th ed. Chichester: Wiley.

Farias DSE, Espindola BP, Claudino DC, Perin EB, 
Bianchini GF, Campos GC, et al. 2005. (Org.) Maracajá. Pré-história e Arqueologia. Editora Unisul.

Grimm EC. CONISS: A Fortran 77 program for stratigraphically constrained cluster analysis by the method of the incremental sum of squares. Comp and Geosci. 1987;13: 13-35.

Hastenrath S. 1991. Climate Dynamics of the Tropics. Dordrecht:Kluwer Academic Publishers.

Hueck K. Distribuição e habitat natural do Pinheiro do Paraná (Araucaria angustifolia). Boletim da Faculdade de Filosofia e Ciências da Universidade de São Paulo - Botânica. 1953; 10: 1-24.

Hueck K. 1966. Die Wälder Südamerikas. Stuttgart: Fischer.

Iriarte J, Behling $\mathrm{H}$. The expansion of Araucaria forest in the southern Brazilian highlands during the last 4000 years and its implications for the development of the Taquara/Itararé. Environmental Archaeology. 2007; 12: 115-127.

Jeske-Pieruschka V, Behling H. Palaeoenvironmental history of the São Francisco de Paula region in southern Brazil during the late Quaternary inferred from the Rincão das Cabritas core. The Holocene. 2012; 22: 1251-1562.

Klein RM. O aspecto dinâmico do pinheiro brasileiro. Sellowia. 1960;12: 17-44.

Klein RM. Southern Brazilian phytogeographic features and the probable influence of upper Quaternary climatic changes in the floris- tic distribution. Boletim Paranaense de Geociências. 1975; 33: 6788.

Leonhardt A, Lorscheitter ML. The last 25,000 years in the Eastern Plateau of Southern Brazil according to Alpes de São Francisco record. J of South Am Earth Sci. 2010;29: 454-463.
Marchant R, Almeida L, Behling H, Berrio JC, Bush M, Cleef A, et al. Distribution and ecology of parent taxa of pollen lodged within the Latin American Pollen Database. Review of Palaeob and Palynol. 2002; 121: $1-75$.

Nimer E. 1986. Climatologia do Brasil. 2. ed. Rio de Janeiro: IBGE.

Reimer PJ, Bard E, Bayliss A, Beck JW, Blackwell PG, Bronk Ramsey C, et al. IntCal13 and MARINE13 radiocarbon age calibration curves $0-50000$ years cal BP. Radiocarbon. 2013; 55: 1869-1887.

Roth L, Lorscheitter ML. Palynology of a bog in Parque Nacional de Aparados da Serra, East Plateau of Rio Grande do Sul, Brazil. Quatern of South Am and Antarc Peníns. 1993; 8: 39-69.

Skidmore T. 2003. Uma História do Brasil. $4^{\text {th }}$ edition.

Stefenon, VM, Behling H, Gailing O, Finkeldey R. Evidences of delayed size recovery in Araucaria angustifolia populations after post-glacial colonization of highlands in Southeastern Brazil. An of the Braz Acad of Sci. 2008; 80: 433-443.

Trindade JPP, Borba MFS. 2011. O manejador e a conservação dos ecossistemas campestres. In: O Bioma Pampa. Bagé: Contribuições Científicas.

Troll C. Das "Baumfarnklima"und die Verbreitung der Baumfarne anf der Erde. In: Beiträge zur Geographie der Tropen, Festschrift für Herbert Wilhelmy. Tüb Geograph Stud. 1970;34: 179-189.

Received: May 31, 2015; Accepted: February 20, 2016. 